\title{
Chapter 4. Functions of political trust in authoritarian settings
}

\section{Authors: Paola Rivetti, Francesco Cavatorta}

\section{Introduction}

The literature on political trust has long emphasised its relevance for democracy and democratic consolidation. All types of trust indeed have been considered as indispensable to the sustainability of a democratic system, given that it supplies democratic or democratising polities with the necessary social and political capital to either remain stable or consolidate democracy. This chapter moves on from these assumptions to review the extant literature on political trust in authoritarian settings, a relatively understudied field. It is contended here that the main contribution of this literature to broader studies of political trust has been the questioning of the inherent connection between political trust and democracy, which implies that political trust cannot exist or is in very low supply in authoritarian settings. In fact, examinations of authoritarianism have demonstrated that the larger political context, regardless of its nature, can generate a specific type of political trust.

The literature on political trust is largely concerned with two sets of questions. First, what are the causes or origins of political trust and second what are its consequences. These two broad questions have been largely applied to the study of democratic settings, but they are important for authoritarian countries, as well where a different kind of political trust might develop and whose function is to strengthen authoritarianism. In this respect we advance the idea that, much like the concept of civil society (Berman 2003; Encarnacion 2006), political trust should be stripped of its implicit normative character. This normativity is the product of the near absence of studies engaging with political trust as a neutral concept in so far as it is often limited to discussions as to how authoritarian settings could transit towards liberal democracy through the production of trust (Almond and Verba 1963; Epstein 1984; Putnam 1993 and 2000; Diamond 1999; Edwards, Foley and Diani 2001). The contention here is that implied normativity of the concept of trust obscures the potential similarities that exist between established democracies and authoritarian settings in the production of political trust. While the latter is believed to be desirable per se, an aspect that emerges from the studies of trust and social capital in authoritarian contexts is the double-edge sword political trust can 
be. Thus, just as it can serve the purpose of democratisation or strengthening democracy, it can also be employed and become functional to the survival of authoritarian rule.

The chapter begins with a discussion on the roots of political trust in authoritarian settings as framed in the debate between culturalism and institutionalism. We then look at the consequences of political trust in authoritarian settings. In the second part of the chapter we highlight the contributions and significance of this field of study to the wider literature on political trust, highlighting in particular the seemingly paradox of authoritarian systems displaying quite high levels of political trust. The concluding part of the chapter presents findings from three case-studies - China, Iran and Morocco - where we tease out some of the definitional and theoretical complexity through an analysis of how in practice political trust works in authoritarian systems.

\section{Roots of political trust in authoritarian settings: Culturalism and institutionalism}

The first question as to what is the origin of political trust in established democracies is built around the 'culturalist' versus the 'institutionalist' debate (Mishler and Rose 2001) and finds a parallel when it comes to analyse authoritarian settings. In this respect there are works attempting to explain the absence of political trust through cultural variables and offer a 'cultural' revolution as the solution to generate it, implying therefore that this constitutes the basis for democratisation. Thus, we have for example links to a specific and often partisan interpretation of religious precepts as an obstacle to the creation of genuine political trust. This is the case of studies looking at the role of Islam in both society and politics, which make the argument that democracy and Islam are incompatible and that therefore 'trust' is not an element that is required to govern in part because the legitimation to rule does not derive from the people (Pipes 2003; Voll 2007). It would be however mistaken to focus simply on Islam, as other religions have served as the variable explaining the absence of political trust and, by implication, democracy. Confucianism, for instance, has been employed to explain the high level of confidence in state institutions in the case of South East Asia irrespective of the authoritarian nature of regimes, because Confucian tradition is seemingly supportive of the values of hierarchy and deference to authority (Fukuyama 1995). In a similar vein Catholicism and its authoritarian hierarchical nature were put forth as explanations for the prevalence of authoritarian regimes in Southern Europe first and Latin America later in the 1970s and 1980s (Wiarda 1981). Other culturalist factors beyond religion that have been employed to explain the absence of political trust in authoritarian countries are tribalism and 
clanism. These factors seemingly characterise Arab countries, but they are also popular when accounting for the absence of both democracy and/or political trust in sub-Saharan Africa (Hodgekin 1956; Coleman 1958 and 1994), post-communist Central Asia or specific territories of Western Europe, like in the case of Banfield's 'amoral familism' argument applied to Southern Italy (1967). Kinship, clanism and tribalism are often connected to the persistence of a pre-modern era, where un-modern cultural values dominate, and are often referred to as an obstacle to the formation of modern-minded social capital and trust that would lead to cultural modernity and democracy (Rudolph and Rudolph 1967; O’Donnell 1996; Lauth 2000).

These culturalist explanations are challenged by institutionalism, which examines the potential for both democratisation and growth of political trust in authoritarian societies. In a sense culturalist explanations find it difficult to come to terms with political change and have a difficult time accounting for it when this occurs, because culturalism is by its very nature seemingly unchangeable. Thus, institutionalists argue that once the institutions - political, economic or social - of a specific setting are modified, attitudes of ordinary citizens will change as well, leading to profound transformations. In this respect political trust not only can be created, but also sustained, particularly if one takes into account the positive spin-offs that transitions to democracy usually generate. This is for instance what Weatherford (1992) contends, as he sees support for institutions as deriving from institutional features such as accountability, efficiency, and procedural and distributive fairness, which can be adopted by newly democratic institutions (see also Chapter 16, by Grimes). Democratic institutions such as elections and checks and balances together with social protection and the pre-eminence of individual freedoms are believed to be the critical factor generating trust of citizens (Levi 1996; Buchanan 2002; Dahl 2006; Goodwin-Gill 2006). The example of the former communist states or Latin American countries suggests that political trust is not therefore culture-driven, but is the product of wider political processes that affect the institutional setup of a country. In particular, Mishler and Rose (2001), as well as Van der Meer in this volume (Chapter 17), argue that trust in institutions is dependent on institutions' performance; whether they are able to satisfy people's expectations or not, thus engendering or weakening political trust. Performance-based theorists, however, disagree over how citizens assess performance, with scholars of newly established democracies emphasising that the political character of institutions matters as much as their ability to deliver satisfactory policy results. In this context formal procedures and their fairness are seen as the most relevant factor in generating trust irrespective of the type of decision taken or policy implemented. In former 
communist countries, for example, people might trust institutions based on the rule of law because the rule of law had been suppressed in the past, regardless of the goal-oriented performance of those institutions (Diamond 1999). This observation seems to suggest that assessment of performance, and in particular of economic performance, might be more significant to citizens living in established democracies, where it is more relevant to the people than the values sustaining institutions (Przeworski et al. 1996; Mishler and Rose 2001; Rothstein 2009).

\section{Consequences of political trust in authoritarian settings: Social capital and consolidation}

The second question on what the consequences of the level of political trust are in any setting has also generated a burgeoning literature that examines two specific outcomes. First is the issue of political trust having an impact on social capital and vice versa (see also Chapter 21, by Liu and Stolle). Here it seems that the trends affecting established democracies and authoritarian or transition countries are divergent. Some scholars indeed hold that, under authoritarian constraints, people lack confidence in each other because distrust is inherent to authoritarian settings as a consequence of the arbitrary nature of the exercise of power or because it is learned through childhood socialisation. The lack of trust is likely to invalidate or damage the production of social capital, which stems from inter-personal trust and is considered crucial to the strengthening of democratic rule (Mishler and Rose 2011; Park 2012). To a large extent this assumption is borne out in practice in the Middle East where the levels of interpersonal trust are very low (Jamal 2007a) even after the Arab uprisings of 2011, as the early findings from the EU-funded Arab Trans project suggest (http://www.arabtrans.eu/news/7060/). On the contrary, in democratic settings where interpersonal and political trust is present and quite high, social capital is likely to be conducive to a path-dependent process, which transmits predispositions toward representative institutions and democratic governance (Paxton 2002).

The literature also investigated the opposite relation, namely the impact of social capital and civic engagement on political trust. Again, this dynamic is expected to be very different in democratic and authoritarian settings. In fact, while increased civic engagement brings enhanced social and political trust in the democracy-dominated industrialized world, the expectation is to find a negative relationship between civic engagement and political trust in the developing authoritarianism-prone world. However, as we will develop later, this expectation is not necessarily met in reality. In short, the traditional literature assumes that 
where civil society activism is strong and diverse, the social capital that is produced has a positive effect on political trust whereas in societies with little civil society activism and therefore low social capital, political trust is either absent or very low. This is in accordance with the normative liberal, neo-Tocquevillian definition of civil society activism and with the correlation between higher level of political trust and democracy. Some of the findings advanced in the literature subscribing to this trend also resonate with modernisation theory, which positively correlates variables such as education with social capital and, therefore, democracy (Rahman 2002; Ciftci and Bernick 2014).

However, these relations between social capital and political trust need to be problematized because more recent empirical findings from a number of authoritarian or semi-authoritarian settings tell different stories that might be diverging not only from the mainstream analysis, but also diverging from one another. Thus, for example, in their study of the Dominican Republic, Espinal et al. (2006) demonstrate that increased civic engagement decreases political trust since it exposes citizens to the illegitimate and corrupt practices of government institutions. Other findings generated in authoritarian or semi-authoritarian settings and poorly consolidated democracies, such as the ones in the Arab world (Rahman 2002; Liverani 2008; Cavatorta and Durac 2010), seem to suggest that social capital is reasonably high and that 'trust' in institutions is also high, although it takes on a rather different meaning from the one generally employed. These findings also resonate with studies on South Asia, where examinations of whether civil society associations contribute to democratic citizenship show that association membership is only weakly related to generalised trust and toleration of social diversity, suggesting that the relationship between civic society activism and political trust across East Asia is more complicated than mainstream assumptions would hold (Park 2012). In fact, it is quite possible that high civil society activism may be an outcome of low political trust.

The second important and interesting outcome of the consequences of political trust has to do with the relationship between political trust and democratic consolidation. In a number of recently democratised polities, whether in Latin America or the Arab world, the expected surge of enthusiasm for the democratic process has not occurred. Quite the opposite in fact, as disenchantment with it is one of the most significant traits in such societies. In addition, individuals display very low levels of both interpersonal trust and trust in the new democratic institutions. The latter have not been able to make a dent in the absence of trust that citizens have in the institutions supposedly representing them (Marzouki 2015). As, Espinal et al. (2006) state in citing Payne et al.'s work $(2002,37)$ 'one review of the data for 
Latin America concluded that disenchantment with democracy and lack of confidence in key political institutions is more than just a reflection of poor economic conditions or dissatisfaction with policy outputs; rather, it appears "rooted in a more basic disappointment" in how fundamental processes, actors, and organizations of democratic systems in the region operate.' Although the state of political trust might no longer be as problematic in 2015 in some countries of the region, similar surveys taken in Eastern Europe suggest that the phenomenon might not be weakening. The main point here again is that there seems to be a normative assumption that democracy is good for political trust and that high levels of social capital are good for trust. In this chapter, rather than attempting to look at authoritarian settings as the negative mirror image of the mainstream discourse about trust and civic engagement in democracies, we problematize definitions and linkages, outlining some interesting empirical connections and offering a more in-depth analysis of three case studies from the Middle East, Central and South East Asia.

\section{Significance of the field of study}

In light of the previous discussion it is worth re-emphasising that when it comes to the role of political trust and social capital in authoritarian settings, many studies have shed light on the surprising findings that emerge. There is a recurring perception that political trust is an inherently democratic trait in so far as open and pluralistic political systems engender the trust of citizens in institutions because there is a widespread belief that such institutions are easily accessed through fair competition within a framework of rule of law. In addition, democratic oversight ensures that all state and public institutions, not only the elected ones, are both accountable and accessible, therefore increasing the political trust of ordinary citizens. This belief has remained resilient despite the fact that, since 1990s, scholars have increasingly paid attention to the declining level of political trust in advanced democracies, as a side-effect of the rise of 'critical citizens' (Crozier et al. 1975; Easton 1975; Norris 1999; Dalton 2000; Pharr and Putnam 2000; Pharr et al. 2000; Hetherington 2006), and despite the fact that at the same time high levels of citizens' confidence in state institutions was being detected in authoritarian contexts (Wang 2005a, 2005b; Wang et al. 2006), particularly the ones associated with economic success (Teorell 2010). Notwithstanding this growing scholarship, the connection between political trust and democratic rule has survived as a theoretical assumption and a 'policy belief.' What is believed to motivate trust in democracies, namely openness, access, and accountability, does not exist in authoritarian settings where arbitrary 
rule, patronage, and absence of pluralism are the dominant traits. In short, distrust is inherent in authoritarian countries and scholars expected authoritarian institutions to be negatively related to trust (Mishler and Rose 2001). However, a closer look at what occurs in many authoritarian settings challenges these assumptions.

\section{Measuring trust in authoritarian societies and the performance paradox}

The main contribution of the scholarship on the role of trust in authoritarian settings has been to problematize the notion that such settings prevent political trust from being created. The empirical reality of at least some authoritarian countries suggests the opposite. For instance, empirical evidence shows that citizens of a number of Asian countries have highly different levels of trust in the political and governmental institutions in their respective societies and where one would expect low levels of trust, namely in rigidly authoritarian countries, these are not found (Shi 2001; Yang and Holzer 2006; Zhao 2009). The case of China is rather illuminating in this respect because ordinary citizens seem to have a very high level of trust in the government and public officials at the central level. Nathan (2003) report the findings of a survey conducted in 1993 on a national representative sample of China. The 94 percent of the respondents agreed or strongly agreed with the statement that, 'we should trust and obey the government, for in the last analysis it serves our interest'. Li (2002) reports that in a recent survey, conducted in rural China between 1999 and 2001, 81 percent of the respondents expressed 'relatively high' or 'very high' levels of trust in the central government. Those expressing 'relatively low' or 'very low' opinions account for less than 4 percent (Li 2004). In a similar vein, Wang (2005b) observes that the 2001 World Values Survey found that close to 90 percent of Chinese citizens express trust in their national government, while only 30-40 percent of US citizens do so. Therefore, studies of political trust in authoritarian settings not only suggest that it does exist but also indicate that nondemocratic institutions or lack of democracy may not be a consequence of low political trust. In fact, low or declining levels of trust are more easily found in democracies than authoritarian regimes, as demonstrated by a number of scholars subscribing to the 'crisis of democracy' argument since the 1990s, or in newly established democracies, as findings suggest that democratization does not necessarily breed political trust (Mishler and Rose 2001; Della Porta 2013). 
Explaining the causes of high public support for government in China or in similarly authoritarian societies is usually dismissed as unnecessary because what is measured does not correspond to the reality (Wang 2005b). First it is held that citizens are intimidated by the state and therefore there is very little to no chance of measuring properly what their views might be. Secondly, there are the effects of the indoctrination theory, which sees the citizens as immersed in the information the state generates, manages, and distributes. Both points have a degree of validity, but at the same time some studies have pointed out that such results are present even when one takes them into account (Chen and Shi 2001), as the differentiation Chinese citizens make between local political authorities (trust in them is low) and the national ones (trust in them is high) indicates. Measuring the degree of intimidation of citizens is particularly difficult and one could for instance assume that such intimidation might not extend to participating in surveys. This might contribute to explain events that seem paradoxical, such as the undeterred support of a reasonably large chunk of the Syrian population for the brutal dictatorship of Bashar al-Assad. Intimidation might be one factor to explain subordination, but might not be the only one. In terms of the argument about management and distribution of information, it is increasingly difficult to make a convincing case given the proliferation of new technologies, as the Arab Awakening has in part demonstrated. Thus, an equally reasonable explanation for seemingly puzzling results is that citizens are indeed satisfied with the performance of the government and, in the case of China or Russia or the Arab Gulf States, this might be true considering the remarkably high rates of economic growth and development.

The point about economic success is relevant, as scholars looking at high levels of trust in authoritarian regimes have pointed to it in order to highlight that satisfaction with economic governance and policies play a role in strengthening trust and vice versa (Kim 2010). While it is true that some scholars of advanced democracies have found that low levels of public trust are not caused by the worsening of government performance as measured by inflation and unemployment rates (Mcallister 1999), such a finding does not necessarily refute the linkage between good performance and high political trust in authoritarian settings, where much of the legitimacy of the regime rests on positive economic performances. In addition, one could argue that the satisfaction of primary economic needs is much more relevant in developing authoritarian countries than in post-materialist established democracies. Finally, more recent literature on established democracies suggests that earlier findings about trust not being affected by economic performance should be revisited because the latter might actually matter in explaining decreasing trust in institutions (Rothstein 2011). 
There are however two caveats to this general finding and they need to be taken into account. First, some of the studies are outdated and the so-called 'paradox of good performance' might be beginning to work, whereby better standards of living and a wealthier middle class could lead to an increasing questioning of the trust the government actually inspires (Goldman and MacFarquhar 1999). The second caveat is about generational attitudes, as younger generations are often much more critical towards political institutions which they are likely to distrust than their parents (see also Chapter 11, by Mayne and Hakhverdian). This is true in China (Wang 2005b), but it is also true across other authoritarian settings such as the Dominican Republic (Espinal, Hartlyn and Kelly 2006) and the Arab world, as the youth-driven Arab awakening suggests (Hoffman and Jamal 2012). In fact, the sociodemographic variables generate some interesting results. In the case of the Dominican Republic, for instance, Espinal, Hartlyn and Kelly (2006) found out that there is a u-shaped relationship between socioeconomic status and political trust. In fact, the poorest and wealthiest trust governments and institutions more than middle-income social sectors. Also, they found a positive impact of age on trust levels. As age increases, trust also increases, with older people trusting institutions more than the youth. This might be due not only to life-cycle effects, but also to cohort effects. The younger generation, socialised in a more globalised, sceptical era with access to diverse information and media outlets, may never be as trusting as the older generation, which grew up in more isolated and 'state-controlled' conditions. Because both life-cycle and cohort effects operate, there is the need for longer-term survey data in order to single these two variables out more precisely. In any case, the age effect on the level of political trust indicates that we can reject the culturalist argument that low levels of trust are influenced by early-life socialisation, confirming what Mishler and Rose (2001) found for post-Communist societies and Espinal, Hartlyn and Kelly (2006) in the case of the Dominical Republic. Scholars of area studies have thus contributed to the study of political trust, demonstrating its existence in authoritarian countries and highlighting its dynamic relationship with institutions' performance and citizens' cohorts.

\section{Trust or predictability?}

A second interesting and oft neglected aspect of the relationship between political trust and state institutions in authoritarian settings has to do with the notion of trust itself, which can be read 'negatively' as well as 'positively.' In a sense, citizens of authoritarian countries, while generally displaying low levels of interpersonal trust, 'trust' the government to take a 
specific course of action when faced with a particular problem. This does not mean that the action of the government will be ethical or legal or just: It simply means that citizens are conscious of and confident that specific institutions of the state will take a routinised decision, and that therefore the state can be relied on to act in very specific and, crucially, expected manner. In short, actions of the institutions of the state become entirely predictable and therefore trustworthy because one knows exactly what will occur in a given scenario. There is the routinisation in some ways of the arbitrary nature of the exercise of power; people operate under the assumption that power is arbitrary, which, paradoxically, provides a degree of certainty in what state institutions will do. The predictability of state actions and responses allows individuals, but also social groups, to know in advance what to expect. An interesting, and probably unusual example is the 2013 documentary The Square about the uprisings in Egypt, where one of the young protagonists of the revolt against Mubarak first and against the Muslim Brotherhood later, spoke of the certainty of the events that would follow each action on the part of the protestors. Ominously, this young protagonist 'trusted' that, faced with the chaos of the political situation under the elected president Mohammed Morsi, the army would carry out a military coup. Conversely, the Muslim Brother in the documentary 'trusted' that the army would open fire on protestors when carrying out the coup. This example is only anecdotal, but it testifies to an element that is often overlooked; you can trust the institutions of the state to follow a set of practices in any given scenario. In authoritarian systems, this routinisation of behaviour is what allows actors to make choices in relative security in relation to their consequences (Levi and Stoker 2000; Lust-Okar 2005). Thus, whereas positive political trust can be defined as trust in ethical, legal or just actions undertaken by the ruling authority, negative trust can be defined as trust in the fact that the authority will act predictably. In both cases trust is political though. Students of the Middle East and North Africa have contributed to expose this distinction by examining case-studies from the region (Jamal 2007b and 2009) and unveiling the negative side of political trust, whereby high levels of trust in the predictable behaviour of authoritarian institutions may be conducive to selfdiscipline and self-censorship (Wiktorowicz 2000; DeFilippis 2001; Rivetti and Cavatorta 2013).

\section{Civil society and trust reconsidered}

A third interesting aspect that emerges from the literature on civic engagement is that trust in state institutions is also dependent on the specific patterns that civil society activism 
creates in authoritarian contexts. For instance, Finkel et al. (2000) argue that in the Dominican Republic engaging in civil society organisations determines lower levels of trust in the government, because civic participation exposes the citizens to the disjuncture between the democratic ideal and the reality, particularly in those cases where civil society organisations are critical of institutions that are perceived as corrupt and illegitimate. Although this holds true for a number of authoritarian settings, we have different stories from the Arab world. Here, the ways in which modern authoritarian states have 'sponsored' the growth of civil society activism have led to significant increases in social capital because groups and associations that work directly or indirectly with the regime without challenging it, are allowed to generate significant benefits for their members (Heydemann 2007; Jamal 2007b). In turn this increases social capital because groups and associations deliver on what they should be doing. Ultimately, this strengthens the authoritarian regime, giving rise to a form of political trust in how authoritarian institutions reward allegiance and absence of contestation. Of course, the relationships of trust that develops in such contexts between activists and state representatives is of a clientelistic and paternalistic nature with significant kin-related undertones, but this should not detract from the fact that goods are nevertheless provided to compliant associations and that the delivery of such goods binds activists to a method of governing that permits the resilience of authoritarian practices. In part this might explain the significant gap between low interpersonal trust in authoritarian settings and the high social capital, however distorted, that authoritarianism produces within civil society. In any case, what clearly emerges from Jamal's study and from similar works is that the notion that civil activism would necessarily lead to democratisation through the generation of 'positive' normative social capital via the acquisition of greater trust does not necessarily hold. All of this is quite problematic for democracy and democratisation because it normalises that authoritarian regimes can deliver widespread benefits and suggests that a number of key social groups trust the system to do so. The positive notion of social capital then gets turned on its head, suggesting that it might have a much greater multifaceted nature than usually believed. This has proven to be the case across different societies, highlighting that cultural specificity might not play a crucial role in this (Cavatorta 2012; Park 2012). In the words of Espinal et al. (2006), this finding provides support for the view that a country like the Dominican Republic possesses both trusting and sceptical democrats, and trusting and sceptical authoritarians. In order to tease out some of these paradoxes and trends and how they work in the daily reality of authoritarian countries we examine three different countries. We first deal with China, a country scholars have paid particular attention to in part because 
of the puzzling combination of high levels of trust in the central government, high economic growth and authoritarian government. Second, we look at Iran because it displays a rather peculiar political system combining genuinely democratic institutions and politics with a clear authoritarian 'superstructure' that constrains the democratic game. Finally, we examine Morocco where the popular legitimacy and liberal policies of the monarchy stand in sharp contrast with the authoritarian nature of its rule.

\section{Political trust in three authoritarian countries}

\section{Social capital and political trust in China}

The case of China is an illustration of the complexity of the dynamics surrounding the linkage between political trust, civil society activism and regime type since, contrary to expectations, civil society is strong and lively in the country. More specifically, it is very active when it comes for instance to environmental protection, whereby the 'greening' of the Chinese state has let environmental NGOs and activism surface (Ho 2001; Ho and Edmonds 2007). Chinese environmentalism has developed gradually, and over the years the country has seen the emergence of a broad range of organisations, albeit fragmented and region-based (Ho 2001; Hess 2013). However, the burgeoning civil activism around environmentalism resulted in the state's growing awareness of the need to control civil society through co-option and taming. Legal expedients were put in place in order to do this, as reported by Ho (2001):

[...] what these rules mean in practice is illustrated by the words of a person who attempted to set up a NGO: "Only if you can find a sponsoring institution willing to be

your 'mother-in-law' (popo) can you register with the Ministry of Civil Affairs. This means that the sponsoring institution has to be responsible for your organization's actions. Nobody dares to be your mother-in-law, as they fear that you will make trouble or arouse the people". $(2001,903)$.

By allowing only some civil society actors to become active, the Chinese state also strengthened linkages of trust among those included and, therefore, strengthened its own rule. There are reasons to suggest that what has been done with environmental civil society can be replicated across a broad range of other issues that are affecting China's economic and political development. The creation and inclusion of civil society organisations within the 
broader framework of state policies pre-empts challenges and, more importantly, can contribute to the growth of political trust because state institutions are perceived to be responding to the needs and issues citizens care about, although within rather strict boundaries. The case of environmental organizations in China is interesting because it seems to suggest that as long as the state is responsive to what can be termed 'a-political' issues then issues that citizens care about can be tackled. In this respect, trust can thus develop. It should be noted however that such political trust in institutions seems to be confined to the central government rather than to the local authorities, which are generally thought of as corrupt or incompetent or both (Wang 2013). The explanation for this might be in part due to the overall economic success China has enjoyed over the last two decades. Such success is believed to be the outcome of highly centralised decision-making and therefore it is plausible to think that ordinary citizens have trust in the leadership. This brings us back to the notion that economic success might be more important in authoritarian states than in established democracies.

\section{Student activism, trust and social capital in Iran}

The Iranian student movement is a good example of how social capital and civic engagement are a factor strengthening political trust, and also authoritarian rule. The presence of a lively student movement is usually equated with an indication of a lively society and social capital (Gouldner 1985; Wickham-Crowley 1992). This positive role has been highlighted in the scholarship in the case of the so-called 'developing world' too. In these countries, student movements are seen as forces of modernisation and thus democratisation (Altbach 1981; Zhao 2004), at the forefront of pro-democracy demonstrations against authoritarian regimes. This is the case for the anti-communist protesters in Tien-An-Men Square in China or the Chilean and Argentinean student unions challenging military rule.

In the case of Iran, the student movement has been widely celebrated as an antiauthoritarian force, as students have often protested against the authoritarian rule in the Islamic Republic (Mashayekhi 2001; Yaghmaian 2002). Despite the fact that universities have been and still are the 'hot bed' of activism and civic engagement, the influence and the workings of authoritarian governance have deeply impacted how such activism effectively operates. Indeed, universities and student unions are often co-opted institutions, where loyalties and political affiliations - which may have future implications beyond the campus are established and reinforced. In particular, the connection between Iranian institutional politics and the university campus, which thus becomes a site for factional recruitment, is 
particularly strong. In line with Amaney Jamal's (2007b) findings, the case-study of the Iranian student movement shows that political trust and the production of social capital in authoritarian settings can have negative consequences when it comes to the implications for democratisation.

The political elite of the Islamic Republic is organised in a highly divided factional system, with factions and groups in flux, whose boundaries and political identity have significantly shifted over the years (Moslem 2002), Often, the origins of political factions and personal connections among politicians and elite members can be traced back to university campuses. A case in point is the historical inter-connectedness of universities, student unions (by means of, on the one hand, the Sazman-e Basij-e Daneshju, a student organisation linked to the revolutionary guards and the conservatives, and on the other hand, of the Daftar-e Tahkim-e Vahdat, traditionally linked to the reformists) and political factions. It is in the ranks of student organisations that many present-day politicians began their careers.

Many among the collaborators of the former president Ahmadinejad have a past in the ranks of the Basij serving on university campuses. Alireza Zakani, a parliamentary deputy close to the former president, is the former head of the Student Basij Organisation, the coordinating authority of all the student Basij units in Iran. Mehrdad Bazrpash, head of the National Youth Organisation, a governmental organisation, until October 2010, is the former head of the Basij unit at Sharif University of Technology in Tehran. Mojtaba Samareh Hashemi was considered to be one of Ahmadinejad's closest collaborators and friends. He managed Ahmadinejad's 2009 electoral campaign, was appointed as deputy Interior Minister in 2007 (a key position for the supervision of electoral procedures) and some of his relatives were appointed in governmental posts too. Like Ahmadinejad, Samareh studied at the Tehran's University of Science and Technology, where they met. In the first postrevolutionary student national election in 1979, Samareh was elected as the representative from Tehran's University of Science and Technology, and Ahmadinejad was his deputy. Among the same university's alumni, many ministers of the presidential cabinet during Ahmadinejad's second mandate (2009-13) can be found (Rivetti 2012).

The strength of the link between institutional politics and student activism within leftist-reformist elite circles is also demonstrated by the close relationship existing between the latter and the Daftar-e Tahkim-e Vahdat (the most prominent Islamic leftist, prodemocracy student organisation, DTV, very active until late 2000s). When Mohammad Khatami launched his presidential campaign in 1996 referring to 'democracy', 'civil society', and 'rule of law', students were called to become active through DTV. During Khatami's first 
mandate as president and on the occasion of the 2000 parliamentary elections, higher education institutions became a stronghold of the reformist coalition Dovvom-e Khordad, which included the DTV. After the coalition won the majority of the seats in the parliament (2000-2004), a 'student faction' was established. It was headed by Ali Akbar Mousavi Khoeini, a former leader of DTV, and several of its members were former DTV prominent members. According to a former member, DTV's enthusiastic embrace of the reformist rhetoric of democracy, civil society and rule of law was in retrospect seen as an alignment with the dominant discourse of the reformist elite (Rivetti and Cavatorta 2013). The DTV was then dependent on the reformist elite in terms of visibility, leadership and intellectual elaboration.

The inter-connectedness of student groups and factional politics shows that social capital and civic engagement may have very different outcomes depending on the characteristics of the context in which they are merged. In authoritarian settings as the Islamic Republic of Iran, the political and intellectual forces student activism produces have ended up feeding the existing status quo, namely authoritarian rule.

\section{Social capital and democratisation in Morocco}

Despite the changes introduced with the constitutional reforms of 2011, Morocco remains an absolutist monarchy with the king retaining wide-ranging executive powers and very little to fear in terms of political opposition to its institutions, as parliament and elected officials are beholden to him (Benchemsi 2012). If executive political powers were not sufficient to make the monarch the real decision-maker, he also retains the legitimating religious title of Commander of the Faithful. Despite the rather clear authoritarian nature of the political system, the monarchy has been able to project a different image internationally where the country is perceived to be gradually democratising and modernising. Central to this image is the activism of Moroccan civil society. The country is home to thousands of civil society organisations dealing with all sorts of different issues and ranging from the protection of the environment to the rights of sub-Saharan migrants and from anti-corruption campaigns to the defense of human rights. In addition, it should be underscored that high levels of activism can be seen in what can be loosely termed the Islamist and secular camps.

However, as Sater (2007, 164-5) argues, 'apart from a few exceptions [civil society groups] are by no means in opposition to the state. In fact ... most of them ... display selflimiting features.' This quote highlights once more the complex nature of the relationship 
between civil society activists, state institutions and trust. The vast majority of organisations in the country that wishes to achieve its goals and generates benefits, both material and moral, for its members has to contend with the authoritarian setting within which it operates, eventually coming to terms with and employing the authoritarian and corrupt practices that the regime has put into place. This should not suggest that all civil society actors are inevitably co-opted. There are organisations that refuse to play within the authoritarian structures and attempt in fact to challenge them through their activism. However, they pay a significant price for this because they do not receive benefits, as they are excluded from the network of privileges guaranteed to more supine associations. In turn this has a negative effect on membership and the generation of social capital, confirming Jamal's findings (2007b). Who would want to be a member of an organisation that is not only unable to attain any of the objectives it has set for itself, but that is also the victim of harassment and threats from the state agencies?

Within this environment, one would expect political, social and economic reforms to be strictly top-down. Civil society associations would bandwagon on whatever is decided at the top of the system and simply attempt to carve out a space to satisfy their members. The reality is, paradoxically, rather different. Civil society autonomously generates, discusses and strives for reforms and the most significant one that has transformed the legal, if not yet the social, landscape of the country is the reform of the Moudawana: Personal status legislation. The reform of the extremely conservative legal code had been a priority for women's rights activists since the early 1990s.. In order to achieve more egalitarian personal status laws, women's rights organisations campaigned extensively, employing all sorts of tactics, including demonstrations, petitions and lobbying. Despite all these efforts, a comprehensive reform was never seriously discussed at the highest levels because it was believed it would alienate powerful conservative constituencies that supported the monarchy. In addition, widespread opposition to the reform came from the very active and powerful Islamist camp of civil society. It is only in the period between 2003 and 2004 that the reform of the family code re-surfaced as an important issue, as the new monarch attempted to secure the support of new domestic constituencies and project a liberalising image abroad to strengthen his grip on power.. Women's rights associations saw an opportunity to place the reform of the family code on the political table and the way in which they went about promoting the reform highlights how political trust can operate under authoritarianism. The liberal content of the reform is a positive development for women and from a normative perspective it is a welcome step. This is beyond questioning in so far as it provides a significant degree of legal equality 
in all matters pertaining to their personal status. However, the reform was obtained only when the women's movement decided to by-pass elected institutions, appealing directly to the executive powers of the King to push through the reform. The monarch was more than happy to do so in order to achieve the two objectives mentioned earlier, having in addition identified the conservative Islamists as the greatest threat to his reign. By becoming le roi des femmes he tied the women's movement to himself, ensuring its allegiance against the rising tide of conservatism and traditionalism. The problem with the process is that it actually highlighted how marginal elected institutions actually are because the reform, no matter how one might be favourable to it, would have never been passed into law because it did not have the backing of the majority of deputies nor the one of the majority of society.

It is interesting to note that trust in the monarch increased considerably within the secular and liberal sector of the population with positive spin-offs as well for those within the women's movement because they were able to achieve what they had set out to do and thereby increase social capital. Such social capital however is not turned towards the achievement of democracy; quite the contrary. In addition, the manner in which the reform was carried out has taught others what the channels and the manners are through which they can operate, further strengthening authoritarian practices.

\section{Conclusion}

The literature on political trust, social capital and civil society activism in authoritarian settings has made a fundamental contribution to our general knowledge of how these concepts function and operate when stripped of their normative understanding. The normative underpinnings of the inevitability of the relationship between these concepts and democracy have characterised the literature for a long time. Findings from authoritarian countries demonstrate that high political trust in state institutions and social capital in wider society can exist and even thrive where there is no political accountability, no rule of law and arbitrary exercise of state power. This tells for instance that notions of trust or social capital or civil society need to be stripped to a large extent of their in-built normativity in order to become useful concepts that can travel across different political systems. In a number of authoritarian settings, as the three case studies presented here suggest, there are significant levels of political trust in institutions even though interpersonal trust might be low and social capital dependent on paternalistic and clientelistic networks. This trust might be 'negative' in the sense that citizens trust the authorities to take specific courses of actions that are arbitrary and 
outside the bounds of the rule of law, but that is in fact the point. Routinizing certainty of responses, even when these are unethical, a-moral and arbitrary, contributes to increase trust. In addition, it appears that two further elements emerge from studying political trust in authoritarian settings. First is the importance of the delivery of material goods. Unlike in established democracies, as some of the literature argues, there is a good case to be made about the tight relationship between trust and economic success. Second, is the significance of legitimacy of rulers. In part of course such legitimacy is once again the product of the delivery of material benefits, but it can also rest on traditions, as in the case of the Moroccan monarchy. All this, in part, might explain why, far from witnessing the end of history, we might actually be experiencing the resilience of authoritarian forms of governance. 


\section{References}

Almond, G. and S. Verba (1963), The Civic Culture: Political Attitudes and Democracy in Five Nations, Princeton, NJ: Princeton University Press.

Altbach, P.G. (1981), 'Student activism in the 1970s and 1980s', in P.G. Altbach (ed.), Student Politics. Perspectives for the Eighties, Metuchen, N.J.: The Scarecrow Press, $1-14$.

Banfield, E. (1967), The Moral Basis of a Backward Society, New York: Free Press.

Benchemsi, A. (2012), 'Morocco: Outfoxing the opposition', Journal of Democracy, 23 (1), 57-69.

Berman, S. (2003), 'Islam, revolution and society', Perspectives on Politics, 1 (2), 257-72.

Buchanan, A. (2002), 'Political legitimacy and democracy', Ethics, 112 (4), 689-719.

Cavatorta, F. (2012), 'Le printemps arabe: Le réveil de la société civile. Aperçu général', Barcelone: Institut Européen de la Méditerranée (IEMed): 83-90.

Cavatorta, F. and V. Durac (2010), Civil Society and Democratization in the Arab World, London: Routledge.

Chen, X. and T. Shi (2001), 'Media effects on political confidence and trust in the People's Republic of China in the post-Tiananmen period', East Asia, 19 (3), 84-118.

Ciftci, S. and E.M. Bernick (2014), 'Utilitarian and modern: Clientelism, citizen empowerment, and civic engagement in the Arab world', Democratization, 1-22. DOI: $10.1080 / 13510347.2014 .928696$.

Coleman, J. (1958), Nigeria: Background to Nationalism, Berkeley: University of California Press.

Coleman J. and R. Sklar (eds.) (1994), Nationalism and Development in Africa, Berkeley: University of California Press.

Crozier, M., S. Huntington and J. Watanuki (1975), The Crisis of Democracy, New York: New York University Press.

Dahl, R.A. (2006), On Political Equality, New Haven, CT: Yale University Press.

Dalton, R.A. (2000), 'Value change and democracy', in S.J. Pharr and R.D. Putnam (eds.), Disaffected Democracies, Princeton: Princeton University Press, 252-69.

DeFilippis, J. (2001), 'The myth of social capital in community development', Housing Policy Debate, 12 (4), 781-806.

Della Porta, D. (2013), Can Democracy Be Saved?, Oxford: Polity Press. 
Diamond, L. (1992), Developing Democracy: Toward Consolidation, Baltimore, MD: Johns Hopkins University Press.

Easton, D. (1975), 'A re-assessment of the concept of political support', British Journal of Political Science, 5 (4), 435-57.

Edwards, B. and M.W. Foley (2001), 'Civil society and social capital: A primer', in B. Edwards, M.W. Foley and M. Diani (eds.), Beyond Tocqueville: Civil Society and the Social Capital Debate in Comparative Perspective, Hanover, NH: Tufts University Press, 1-14.

Encarnacion, O. (2006), 'Civil society reconsidered', Comparative Politics, 38 (3), 357-76.

Epstein, E.C. (1984), 'Legitimacy, institutionalization, and opposition in exclusionary bureaucratic authoritarian regimes: The situation of the 1980s', Comparative Politics, 17 (1), 37-54.

Espinal, R., J. Hartlyn and J.M. Kelly (2006), 'Performance still matters: Explaining trust in government in the Dominican Republic', Comparative Political Studies, 39 (2), 20023.

Finkel, S.E., C.A. Sabatini and G.G. Bevis (2000), 'Civic education, civil society, and political mistrust in a developing democracy: The case of the Dominican Republic', World Development, 28 (11), 1851-74.

Fukuyama, F. (1995), 'Confucianism and democracy', Journal of Democracy 6 (2), 20-33. Goldman, M. and R. MacFarquhar (1999), 'Dynamic economy, declining party-state', in M. Goldman and R. MacFarquhar (eds.), The Paradox of China's post-Mao Reforms, Cambridge, MA: Harvard University Press, 3-29.

Goodwin-Gill, G. (2006), Free and Fair Elections, Geneva: Inter-Parliamentary Union.

Gouldner, A. (1985), Against Fragmentation: The Origins of Marxism and the Sociology of Intellectuals, Oxford: Oxford University Press.

Hess, S. (2013), 'From the Arab spring to the Chinese winter: The institutional sources of authoritarian vulnerability and resilience in Egypt, Tunisia, and China', International Political Science Review, 34 (3), 254-72.

Hetherington, M.J. (2006), Why Trust Matters: Declining Political Trust and the Demise of American Liberalism, Princeton, NJ: Princeton University Press

Heydemann, S. (2007), 'Upgrading authoritarianism in the Arab world', Analysis Paper, The Saban Center, Number 13, March. Available at: http://www.brookings.edu/ /media/research/files/papers/2007/10/arabworld/10arabwo rld. 
Ho, P. (2001), 'Greening without conflict? Environmentalism, NGOs and civil society in China', Development and Change, 32 (5), 893-921.

Ho, P. and R. Edmonds (eds.) (2007), China's Embedded Activism: Opportunities and Constraints of a Social Movement, London: Routledge.

Hodgekin, T. (1956), Nationalism in Colonial Africa, London: Frederick Miller.

Hoffman, M. and A. Jamal (2012), 'The youth and the Arab spring: Cohort differences and similarities', Middle East Law and Governance, 4 (1), 168-88.

Jamal, A. (2007a), 'When is social trust a desirable outcome? Examining levels of trust in the Arab world', Comparative Political Studies, 40 (11), 1328-49.

Jamal, A. (2007b), Barriers to Democracy: The Other Side of Social Capital in Palestine and the Arab World, Princeton: Princeton University Press.

Kim, S. (2010), 'Public trust in government in Japan and South Korea: Does the rise of critical citizens matter?', Public Administration Review, 70 (5), 801-10.

Lauth, H. (2000), 'Informal institutions and democracy', Democratization, 7 (4), 21-50.

Levi, M. (1996), 'Social and unsocial capital: A review essay of Robert Putnam's making democracy work', Politics and Society, 24 (1), 45-55.

Levi, M. and L. Stoker (2000), 'Political trust and trustworthiness', Annual Review of Political Science, 3 (1), 475-507.

Li, L. (2004), 'Political trust in rural China', Modern China, 30 (2), 228-58.

Liverani, A. (2008), Civil Society in Algeria, London: Routledge.

Lust-Okar, E. (2005), Structuring Conflict in the Arab World, Cambridge: Cambridge University Press.

Marzouki, N. (2015), 'Tunisia's rotten compromise', Middle East Research and Information Project, July 10, Available at: http://www.merip.org/mero/mero071015.

Mashayekhy M. (2001), 'The revival of the student movement in post-revolutionary Iran', International Journal of Politics, Culture and Society, 15 (2), 283-313.

McAllister, I. (1999) 'The economic performance of governments', in P. Norris (ed.), Critical Citizens: Global Support for Democratic Government, Oxford: Oxford University Press, 188-203.

Mishler, W. and R. Rose (2001), 'What are the origins of political trust? Testing institutional and cultural theories in post-communist societies', Comparative Political Studies, 34 (1), 30-62.

Moslem, M. (2002), Factional Politics in Post-Khomeini Iran, Syracuse: Syracuse University Press. 
Nathan, A. (2003) 'Authoritarian resilience', Journal of Democracy, 14 (1), 6-17.

Norris, P. (ed.) (1999), Critical Citizens: Global Support for Democratic Government, Oxford: Oxford University Press.

O'Donnell, G. (1996), 'Illusions about consolidation', Journal of Democracy, 7 (2), 34-51.

Park, C. (2012), 'Associations, social networks, and democratic citizenship: Evidence from East Asia', Taiwan Journal of Democracy, 8 (2), 35-50.

Paxton, P. (2002), 'Social capital and democracy: An interdependent relationship', American Sociological Review, 67 (2), 254-77.

Payne, M., D.G. Zovatto, F. Carrillo Florez and A. Allamand Zavala (2002), Democracies in Development: Politics and Reform in Latin America, Washington DC: Johns Hopkins University Press for IDB and IDEA.

Pharr, S.J. and R.D. Putnam (2000), Disaffected Democracies: What's Troubling the Trilateral Countries?, Princeton, NJ: Princeton University Press.

Pharr, S.J., R.D. Putnam and R.A. Dalton (2000), 'A quarter century of declining confidence', Journal of Democracy, 11 (2), 5-25.

Pipes, D. (2003), In the Path of God: Islam and Political Power, New York: Transaction.

Przeworski, A., J. Alvarez, J. Cheibub and F. Limongi (1996), 'What makes democracies endure?', Journal of Democracy, 7 (1), 39-55.

Putnam, R.D. (1993), Making Democracy Work: Civic Traditions in Modern Italy, Princeton: Princeton University Press.

Putnam, R.D. (2000) Bowling Alone: The Collapse and Revival of American Community, New York: Simon and Schuster.

Rahman, M.A. (2002), 'The politics of 'uncivil'society in Egypt', Review of African Political Economy, 29 (91), 21-35.

Rivetti, P. (2012), 'Student movements in the Islamic Republic: Shaping the country's politics through the campus', Chaillot Paper 128, 81-101.

Rivetti, P. and F. Cavatorta (2013), “The importance of being civil society': Student politics and the reformist movement in Khatami's Iran', Middle Eastern Studies, 49 (4), 64560.

Rothstein, B. (2009), 'Creating political legitimacy: Electoral democracy versus quality of government', American Behavioral Scientist, 53 (3), 311-30.

Rothstein. B. (2011), The Quality of Government: The Political Logic of Corruption, Inequality and Social Trust, Chicago: University of Chicago Press. 
Rudolph L. and S. Rudolph (1967), The Modernity of Tradition: Political Development in India, Chicago: University of Chicago Press.

Sater, J.N. (2007), Civil Society and Political Change in Morocco, London: Routledge.

Shi, T. (2001), 'Cultural values and political trust: A comparison of the people's Republic of China and Taiwan', Comparative Politics, 33 (4), 401-19.

Teorell, J. (2010), The Determinants of Democratization, Oxford: Oxford University Press. Voll, J.O. (2007), 'Islam and democracy: Is modernization a barrier?', Religion Compass, 1 (1), 170-8.

Wang, Z. (2005a), 'Political trust in China: Forms and causes', in L. White (ed.), Legitimacy: Ambiguities of Political Success or Failure in East and Southeast Asia, Singapore: World Scientific, 113-39.

Wang, Z. (2005b), 'Before the emergence of critical citizens: Economic development and political trust in China', International Review of Sociology, 15 (1), 155-71.

Wang, Z. (2013), 'Institutional trust in Asia', Paper prepared for the Asian Barometer Conference, Taipei, June 17-19, Available at: https://www.academia.edu/5070458/Institutional_Trust_in_East_Asia.

Wang, Z., R.J. Dalton and D.C. Shin (2006), 'Political trust, political performance, and support for democracy', in R.J. Dalton and D.C. Shin (eds.), Citizens, Democracy, and Markets Around the Pacific Rim, Oxford: Oxford University Press, 135-55.

Weatherford, M.S. (1992), 'Measuring political legitimacy', American Political Science Review, 86 (1), 149-66.

Wiarda, H. (1981), 'Toward a framework for the study of political change in the Iberic-Latin tradition: The corporative model', World Politics, 25 (2), 206-35.

Wickham-Crowley, T. (1992), Guerrillas And Revolution In Latin-America, Princeton, N.J.: Princeton University Press.

Wiktorowicz, Q. (2000), 'Civil society as social control: State power in Jordan', Comparative Politics, 33 (1), 43-61.

Yaghmaian, B. (2002), Social Change in Iran: An Eyewitness Account of Dissent, Defiance, and New Movements for Rights, New York: State University of New York Press.

Yang, K. and M. Holzer (2006), 'The performance-trust link: Implications for performance measurement', Public Administration Review, 66 (1), 114-26.

Zhao, D. (2004), The Power of Tiananmen: State-society Relations and the 1989 Beijing Student Movement, Chicago: University of Chicago Press. 
Zhao, D. (2009), 'The mandate of heaven and performance legitimation in historical and contemporary China', American Behavioral Scientist, 53 (3), 416-33. 